\title{
Educating South Asia's Internally Migrating Children
}

\author{
Caroline Dyer and Vijitha Rajan
}

\section{Contents}

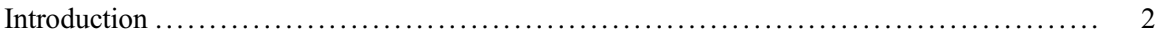

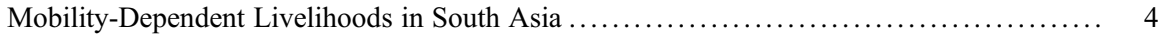

"Migrants" in the Policy Gaze: Multiple Exclusions .............................. 7

Understanding Stocks and Flows of Internally Migrating Populations ................. 7

Identifying Mobile Out of School Children .................................... 8

Enabling the Right to Education for All Children ................................. 9

Education, Human Capital Development, and Poverty Alleviation ................... 11

Approaches to Education Inclusion for Internally Migrating Children .................. 14

An Ontological Crisis? Modern Schooling and Its Terms of Inclusion ................ 14

Leaving No-One Behind by Increasing Education System Flexibility ................ 16

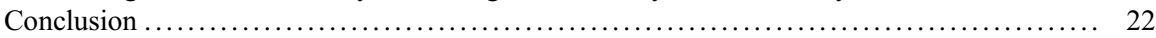

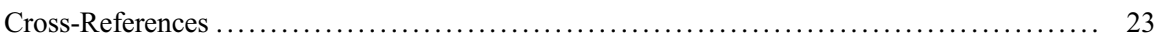

References $\ldots \ldots \ldots \ldots \ldots \ldots \ldots \ldots \ldots \ldots \ldots \ldots \ldots \ldots \ldots \ldots \ldots \ldots \ldots \ldots \ldots \ldots \ldots \ldots \ldots \ldots \ldots \ldots \ldots \ldots \ldots, 23$

\section{Abstract}

Significant progress has been made in South Asia towards extending access to primary education, but as this progress has largely been made by expanding formal schooling suited to sedentary populations, children from migrating communities remain widely excluded. This chapter explores the educational landscape for internally migrating children, focusing specifically on children in mobile pastoralist and seasonal migrant families. Many of these children are out of school, and some are unlikely ever to enroll. They are often absent from, or misrepresented in, education policies and in datasets that inform development policies in the education sector and more widely. Tensions over the legitimacy of

\section{Dyer $(\bowtie)$}

School of Politics and International Studies, University of Leeds, Leeds, UK e-mail: C.Dyer@leeds.ac.uk

V. Rajan

Department of Education, University of Delhi, Delhi, India

e-mail: vijitha.rajan@apu.edu.in 
mobile occupations in modern societies shape differing views of the value of inclusion in formal schools, while non-formal arrangements that could accommodate them are sporadic and unsustained. By foregrounding how internally migrating populations are situated within the promises of "Education for All," this chapter argues that contemporary policy mandates around ideas of "leaving no one behind" and "reaching the furthest behind first" require concerted effort to understand why challenges of access, participation, and retention persist for these children. It calls ultimately for closer engagement with the normative framing of education inclusion.

\section{Keywords}

Education inclusion · Education exclusion - Migration and education · Migrant children $\cdot$ Pastoralist migration $\cdot$ Seasonal migration $\cdot$ Education for All

\section{Introduction}

The Education for All (EFA) movement and successive UN-led Monitoring Reports (e.g. Reaching the Marginalized (GMR 2010); Education for All 2000-2015: Achievements and Challenges (GMR 2015); and Education and Migration (GEMR 2018) have played an important global role in highlighting that migrating groups are highly marginalized in education provision around the world (Dyer 2014). The Sustainable Development Goal (SDG) framework recognizes "migrants" as one of the most vulnerable communities who must be "empowered" and provided "inclusive and equitable quality education" (UN 2015). In light of poor progress, and the SDG agenda's explicit commitment to "leave no one behind" and to "reach the furthest behind first" (UN 2015), why migrating children have been so "left behind" by the EFA movement (Dyer 2014, 2016) requires close attention.

Migration and mobility, and how they are used in this chapter, require some introductory explanation. The focus here is on children in families who use spatial mobility as a livelihood strategy (Dyer 2014, 2016), and who generally migrate internally, i.e. within the boundaries of one country. This focus is deliberate, because ironically, these children are at risk of being further marginalized by current discourses around "migrants." Among "migration" scholars, given the concern over refugee and displacement-related migration, there is a sharp focus on international, cross-border migration (Dyer 2018). The SDG framework also implicitly assumes that "migrants" are "refugees" and "displaced" persons. Globally, however, the numbers of people undertaking various forms of internal migration are far higher than numbers of those who cross national borders to work (Bengtsson and Dyer 2017; IOM 2019). This global trend is also found in South Asia, where there is large scale "within country migration," and temporary and seasonal migration is more prominent than permanent migration (Babu et al. 2017).

The "internally migrating" children of our title are not homogenous. Although they are unified by the centrality of mobility to their lives, there are enormous 
differences in their lived realities. Policy discourses, in contrast, tend to refer to such children in largely undifferentiated, standard categories such as "migrants," "nomads," and/or the "hard to reach" because they do not fit into the mainstream schooling system. Disaggregation of such categorization is critical to understanding how persistent education inequalities relate to particular livelihoods and associated patterns of migration (Dyer 2014) and to addressing them through differentiated interventions that respond to specific circumstances (Bengtsson and Dyer 2017; Dyer 2016). Yet, academic and policy attention to the relationship between internal migratory patterns and education in South Asia is limited (Bernard et al. 2018; GEMR 2018; Smita 2008; Bengtsson and Dyer 2017; Dyer 2016).

In South Asia, irrespective of differences around legal mandates on educational provisioning and their actual manifestations at ground level, a receptive political environment towards global goals and policies for EFA has emerged (Bajaj and Kidwai 2016). Yet systemic under-investment in the education sector persists (Béteille et al. 2020). In India, Pakistan, Afghanistan, and Bangladesh, the "learning crisis" (GMR 2015) is evidenced by estimates that more than half of the children leaving primary school do not attain basic foundational skills (Brinkmann 2017). According to Béteille et al. (2020), South Asia has around 20 million children in "learning poverty." Most of them have schooling experiences that are all too often still characterized by rote learning, corporal punishment, and discrimination (UNICEF 2015). The implications of poor-quality schooling are even more complex for migrating children, whose lived realities are even less adequately recognized or addressed in educational policy and practices. They remain among the most excluded from formal education services (Bengtsson and Dyer 2017; Chandrasekhar and Bhattacharya 2018; CIER and UNICEF 2009; Dyer 2016; GEMR 2018; UNICEF 2014).

Their exclusion reflects the often vast gaps between the provision that is available and the ground realities of migrating children's lives. These gaps give rise to numerous barriers to initial access, participation, and progression (UNICEF 2014). But at a normative level, exclusion is linked to unshared assumptions that modern education has intrinsic value, particularly in relation to formal, fixed-place schooling which is its most prevalent form. The legitimacy of occupations that require continuing mobility in a world that largely adheres to a sedentary norm of human being is also questioned. Thus, mobility is widely assumed to impose a barrier to schooling, yet the sedentary "terms of inclusion" of schools themselves are rarely articulated (Dyer 2012). These kinds of assumptions around sedentary modes of living are also dominant in discourses of modern childhood, normatively understood as a site of "residential fixity" and "domestication," which in turn has led to "moral panic" around the lives of children who are mobile (Ní Laoire et al. 2010). There is a sedentary bias in perceptions of what development is, and policy documents frequently ignore mobility, or define it as a problem (de Haan and Yaqub 2010).

This chapter explores the educational landscapes of internally migrating children and discourses around their educational inclusion, with a focus on India, Bangladesh, Pakistan, and Afghanistan. The literature available on this topic for the region is very slim, and while these four countries are represented, there are more studies for 
India. Since directly comparable data on different parameters is not available, we focus on laying out larger issues and challenges of education inclusion for migrating children, as we have defined them here, and refer where possible to specific country examples.

Section "Mobility-Dependent Livelihoods in South Asia" introduces livelihoods that involve mobility in South Asia. It provides an overview of mobile pastoralism and of seasonal migration in the region and attempts to provide some sense of scale and prevalence despite numerous information gaps. Section "Migrants' in the Policy Gaze: Multiple Exclusions" examines "migrants" in the policy gaze, highlighting the ways in which such groups are rendered invisible or inaccurately represented, and the difficulties of differentiating migrating children among all Out of School Children (OOSC) - all of which impose barriers to inclusive education programming. Section "Enabling the Right to Education for all Children" focuses on enabling the right to education, which is problematised with reference to the idea of education as an individual right, the imperatives of human capital formation within which mobile groups have a poor fit, and the assumptions that schooling can - and should - alleviate poverty. Section "Approaches to Education Inclusion for Internally Migrating Children" examines approaches to education inclusion for internally migrating children: it first examines formal schooling and its "terms of inclusion" to suggest that modern education is in an ontological crisis. It then examines nonformal provision and the supplementary and alternative initiatives that have emerged to accommodate migrating children. The conclusion draws together key findings and highlights the need for sustained and rigorous scholarship.

\section{Mobility-Dependent Livelihoods in South Asia}

No comprehensive and systematic literature is currently available to understand the complex mobility patterns of internally migrating populations in South Asian countries (Babu et al. 2017; Bengtsson and Dyer 2017; UNICEF 2014). In the migration literature, terms used to indicate variations in migration patterns feature aspects such as distance (international/regional/internal), duration (permanent/semipermanent/ temporary/seasonal), pattern (rural-rural/rural-urban/urban-rural/urban-urban), and nature (economic migrants/ political migrants/environmental migrants/refugees/asylum seekers/internally displaced persons/stateless persons) (e.g., IOM 2019). These categories often cannot be neatly defined as there are multiple intersections and complexities around them that vary across countries. Furthermore, mobile pastoralists generally fall outside the purview of "migration" scholars (Dyer 2012, 2018), although the UN's 2018 GEMR does note, in its chapter on internal migration (chapter 2), that both pastoralist and seasonally migrating children are denied their right to education and devotes a subsection to each (GEMR 2018). The lack of systemic and comparable data across South Asian countries makes it difficult to understand the actual scale and nature of the various forms of mobility (Srivastava and Pandey 2017) and how education systems could better respond. 
Mobile pastoralism receives very little attention in South Asian policy discourses and scholarly work (see Agrawal and Saberwal 2004; Sharma et al. 2003; Rao and Casimir 2003; Dyer 2014; Sharma 2011). Some sources refer to mobile pastoralists as "nomads" or "nomadic pastoralists": global scholarship now tends to use "mobile pastoralists," a distinctive term that draws in both mobility and livelihood type. Mobile pastoralists are domestic livestock herders who move with their animals in a production system that seeks to balance pastures, livestock, and people and is uniquely suited to uncertain and variable environments. Mobile pastoralism is practiced across South Asia's drylands and mountainous areas in Afghanistan, Bhutan, India, Nepal, and Pakistan (Sharma et al. 2003; Rao and Casimir 2003; Dyer 2014). Consistent with this ecological variation, the animals herded include yaks, camels, cattle, sheep, goats, and even ducks in the south of India. Well-known examples of pastoralist communities in the region include Kuchi, Bakkerwal, Raika, Gaddi, Gujjar, and Rabaris. Although it is virtually impossible to provide accurate numbers for our focal countries, estimated numbers are about 30 million for India, 1.2 for Pakistan, and around 2 million for Afghanistan (Dyer 2014).

Many pastoralists in the region practice seasonal transhumance: in mountainous regions, much migration is "vertical" - up for summer pastures and down for winters; and elsewhere is "horizontal," across the plains (Sharma et al. 2003). While broad patterns of timing and direction are relatively constant, day-to-day movement responds to local variability. In South Asia, mobile pastoralists often inhabit what have now become the border regions of modern states. Some have adapted their migratory patterns to pursue "internal" migration only, while others may search for fodder or water across national boundaries, which have limited relevance to pastoralists as markers of belonging. These characteristics of pastoralist movement have led to inaccurate external perceptions of "willful wandering" within an outdated mode of social organization, in a livelihood that is at best obsolescent in the modern economy and is also a threat to the environment and wildlife conservation. Such myths belie the sophistication and continuing contemporary importance of mobile pastoralism as a dryland livelihood.

Nevertheless, mobile pastoralism is increasingly affected by policies that adversely affect its sustainability (Dyer 2014) and lack of political representation. The South Asia Pastoralist Alliance, a much needed regional platform that was founded in 2015 to advocate for pastoralism, sets out the key problems for pastoralists in the region: decreasing grazing land and fodder supplies and ineffective policies to address constraints; poor access to markets; missing information on pastoralist systems in South Asia; and education and healthcare services for people and animals that are not adapted to mobile livelihoods (WAMIP 2015).

Two examples illustrate some of the confusions that abound in how states "see" mobile pastoralists. In Afghanistan, policy documentation uses the generic term "Kuchi" for all mobile pastoralists although Kuchis do not share a single ethnicity, language, or religion, and it is imprecise about whether Kuchis are sedentary, mobile, practicing animal husbandry, or exited pastoralists (Dyer 2016). This leads to confusion about which government department is responsible for "Kuchi" development (Sharifi 2013). Insecure conditions have precluded a comprehensive national 
population census, and the "Kuchi" population is estimated to comprise about two million people (Dyer 2016). In India, there is inconsistency across and even within States in relation to including pastoralists as Scheduled Tribes (ST), which provides an entitlement to state protection: Gujjars are found in several States and are classified as ST in some but not in others; and within Gujarat, most members of the Rabari community are classified as Other Backward Class while those who live in Sasan Gir have been given ST status.

Seasonal migrant workers are, according to the definition of the 1990 International Convention on the Protection of the Rights of All Migrant Workers and Members of Their Families, Article 2 (b) (UN 1990), those "whose work by its character is dependent on seasonal conditions and is performed only during part of the year" (ibid UN 1990, p. 2). Seasonal and short-term internal migration in South Asia consists of variety of labor movements: the patterns are often complex and depend on various factors such as the length of migration cycles; annual frequency of migration; type of destination; nature of work; and whether migration is undertaken by single individuals or families (Srivastava 2012). Prominent sectors in which seasonal and short-term migrants are employed in South Asia include garment/ textile industries, construction and domestic work, plantation work, mining and fishing sectors, brick making, salt making, tile making, charcoal making, rice mills, sugar cane harvesting, and stone quarrying. Some of these are "hazardous" forms of labor, as designated by the International Labour Organization, and impose exploitative conditions for children's labor.

As with mobile pastoralists, numbers of internally migrating populations are not accurately known; in India, there are an estimated 100 million circular migrants (Deshingkar and Akter 2009). However, various micro studies and surveys show that in South Asia, short-term and seasonal migration is rising. The determining factors of such migration involve a range of choices and structural factors (Babu et al. 2017) but are often closely linked to agricultural distress and diminishing work opportunities in rural areas. Many individuals and families move to informal settlements in urban areas and work in informal labor sectors (Deshingkar et al. 2012), although in India (and Nepal), rural-to-rural migration remains the prominent form of internal migration (Srivastava and Pandey 2017). Migration from agriculturally poorer regions to rural irrigated areas and to urban informal and manufacturing sectors is growing increasingly predominant in India, Pakistan, and Bangladesh (Deshingkar et al. 2012; Deshingkar and Grimm 2004). Patterns of seasonal and short-term movements also often contrast with permanent and semi-permanent movements. For example, in India, more than half of all temporary and seasonal migrants belong to the rural-urban stream (Keshri and Bhagat 2012), but around $62 \%$ of the total internal migrants undertake rural-rural migration (GoI 2010).

Attempts to restrict migration to urban areas through measures such as rural employment programs and anti-slum drives (Deshingkar 2006) reflect hierarchical understandings of migration, where rural-urban "distress" migration is assumed to be of "low quality" and to create urban disarray, despite the positive contributions migrants make to both source and destination areas. 
Table 1 Determinants of internal migration in the South Asian region

\begin{tabular}{l|l|l}
\hline Country & $\begin{array}{l}\text { No. of studies } \\
\text { reviewed }\end{array}$ & Determinants \\
\hline Nepal & 13 & $\begin{array}{l}\text { Civil conflict, armed violence, environmental stress, poverty, } \\
\text { employment, landlessness, education, marriage }\end{array}$ \\
\hline Pakistan & 5 & $\begin{array}{l}\text { Labor market pressures, unemployment, seeking better } \\
\text { employment and education opportunities, demographic } \\
\text { changes, interregional variations in development }\end{array}$ \\
\hline Sri Lanka & 6 & $\begin{array}{l}\text { Environmental factors, poverty, lack of land, employment, civil } \\
\text { war }\end{array}$ \\
\hline Afghanistan & 5 & Civil war, human trafficking, poverty, employment \\
\hline Bangladesh & 11 & Employment, remittances, climate change, education \\
\hline Bhutan & 1 & Poverty \\
\hline India & 27 & $\begin{array}{l}\text { Poverty, employment, environmental factors, livelihood, } \\
\text { education, agrarian distress, urbanization }\end{array}$ \\
\hline
\end{tabular}

Source: Adapted from Babu et al. (2017)

Table 1 provides a summary of the determining factors of internal migration in different South Asian countries that Babu et al. (2017) identify from their review of literature.

While its overview is useful, in respect of our topic, the Babu et al. (2017) review has significant limitations of scope. The migration studies it reviews comprise seasonal migration (18\%), temporary migration (38\%) and circular migration $(3 \%)$, permanent migration $(38 \%)$ and forced migration $(3 \%)$, but pastoralist movement is not included in their definition of "internal migration".

\section{"Migrants" in the Policy Gaze: Multiple Exclusions}

The 2030 Agenda for Sustainable Development calls for "high quality, timely and reliable" data, including migratory status, to envision systemic change (UN 2015). This section sets out two key challenges to this intention for the South Asia region.

\section{Understanding Stocks and Flows of Internally Migrating Populations}

The scarcity of accurate data about the extent of internal migration in South Asia, particularly that which is seasonal and circular (GEMR 2018), has implications for inclusive education sector programming. In the region (as indeed elsewhere), there has been a lack of political commitment to counting the marginalized; there are differential jurisdictions; definitional ambiguities abound; and methodological weaknesses of enumeration mechanisms omit many mobile populations by design (Carr-Hill 2012). Births of migrating children are not always registered, which makes them "invisible" in official records (CIER and UNICEF 2009). 
Enumerations tend to focus on population stocks (absolute numbers at a given moment), but policy and education service provision also need to understand population flows (movements over a given interval of time) (Deshingkar and Akter 2009). Mechanisms currently in use may capture permanent and semi-permanent movement, but not movement that is short term and seasonal (Srivastava 2012; Srivastava and Pandey 2017) or highly variable. The data they generate may thus provide a misleadingly static snapshot. Even when there is an attempt to capture short-term movements, various problems arise with respect to definitions employed. For example, India's National Sample Survey Office (NSSO) (from its 55th round onwards) attempts to capture short-term movements separately, and in the 64th round, short-term migrants are defined as people who "stayed away from the village/town for a period of 1 month or more but less than 6 months during the last 365 days for employment or in search of employment" (GoI 2010). This definition of short-term migration does not capture movements that people undertake for time periods less than or beyond the parameters it sets out (Chandrasekhar and Bhattacharya 2018; Srivastava 2012). Bengtsson and Dyer (2017) found, for example, that children in families who earn their living from the charcoal industry in India have several intermittent absences from school for about 3 weeks each during the annual school cycle.

\section{Identifying Mobile Out of School Children}

UNICEF's current estimates of OOSC in South Asia put totals at about 11.3 million at primary level and 20.6 million at lower secondary level (UNICEF 2015), while Béteille et al. (2020) report a higher total of around 35 million children, which includes girls, migrant children, and children living in conflict areas. Aggregated data, however, inadequately capture the status of mobile children (UNICEF 2014). Many Mobile Out of School Children (MOOSC, cf. Dyer and Echessa 2019) are likely to be overrepresented among OOSC statistics yet are paradoxically largely invisible within reporting. Identifying MOOSC specifically among all OOSC is made difficult by insufficient definitional and methodological clarity.

This dilemma is captured in UNICEF's (2014) South Asia regional study, which identifies children from families who migrate seasonally for work, among other widely recognized groups such as girls and street children, but does not specifically mention mobile pastoralists. It points out that there are data limitations that prevent analysis of "some specific groups of marginalised children who are disproportionally excluded from school" (UNICEF 2014, p. 10). Many such children, for reasons discussed below, are among those never likely to enroll in formal schooling.

The term OOSC itself represents a static duality, where children are either in or out of school. Yet children in migrating communities are often "nominally enrolled" (Srivastava and Dasgupta 2016): they begin the school year in the home village and their names remain in the home school register even when they move out (Chandrasekhar and Bhattacharya 2018). Irregular attendance patterns are often not taken into account while calculating the number of OOSC (Bhatty et al. 2017), which 
means that children's school absence is poorly recorded and under-reporting is widespread. Alert to these issues, the Indian state of Karnataka changed the definition of "drop out" in 2013 from "continuous absence of a child for 60 days" to "continuous absence of child from the school for seven days" (Rajan 2019).

Current Education Management Information Systems (EMIS) and other reporting mechanisms are largely still unable to disaggregate learner data in ways that support contextualized planning (UNICEF 2014).

\section{Enabling the Right to Education for All Children}

Based on criteria of constitutional and legal provisioning, Bajaj and Kidwai (2016) classify South Asian countries such as India and Sri Lanka as providing a full constitutional guarantee of free and compulsory education; and Afghanistan, Bangladesh, Bhutan, Maldives, Nepal, and Pakistan as providing a partial guarantee. This classification may change with recent developments such as Nepal's adoption of a Free and Compulsory Education Act, 2018 which provides a constitutional guarantee to every child who has completed 4 years but not completed 13 years of age.

South Asian countries have all moved towards adopting rights-based approaches towards formal education. In Sri Lanka, the right to free education was mandated even prior to its political independence and has been in place since 1945 for children aged between 5 and 16. India's 2009 Right to Education (RtE) Act, mandates free and compulsory education for children between the ages 6 and 14. Bangladesh introduced its Right to Education Act in 1990, although it is restricted to compulsory primary schooling only. Pakistan brought in Article 25A through a constitutional amendment in 2010, which enables free and compulsory education to all children aged 5-16, but the legislative measures needed to support this are still absent, except in the Islamabad Capital Territory (Khattak 2018). Afghanistan stipulates in Article 43 of its Constitution of 2004 that education until Bachelor's level is the right of all citizens; Grades 1-9 are compulsory according to the 2008 Education Law.

Afghanistan is highly unusual in the region in making an explicit commitment to improving the education of "nomads" in Article 44 of the 2004 Constitution. This commitment was followed up in policies such as the 2008 Afghan National Development Strategy, the 2008 Education Law, successive National Education Strategic Plans, the 2007 National Action Plan for the Women of Afghanistan and the 2009 Needs and Rights Assessment on Inclusive Education - all of which consistently note the need to include "nomadic" groups alongside females, members of minority groups, and persons with disabilities (Dyer 2016).

Despite the presence of these varying degrees of constitutional and legislative guarantee, "education" is persistently conflated with schooling, and policy discourses also widely assume that - albeit with minor additions such as bridge schools and accelerated learning programs - place-based schooling can be fully inclusive. Yet studies in various South Asian countries show that migrating children face 
challenges with respect to even physical access to schooling in destination areas (Roy et al. 2015) as well as en route (Dyer 2014).

At household level, the notion of an individual right may be in tension with other factors underpinning decision-making in relation to formally educating every child in the family. For example, Dyer (2014) reports from Western India that household splitting enables some pastoralist children to access schooling by staying in the home village with older relatives while their parents/older boys continue to move with animals. In the long term, school attendance can help diversify income generating capabilities, which mitigates the risk of a household's over-dependence on animal rearing, but it is not seen as an individual right.

Attendance at school is also shaped by gender norms. Studies of seasonal migration tend to show that the gendered nature of domestic work, coupled with difficult living and working conditions in the city, have more negative impacts for women's and girls' welfare and education than they do for men and boys (Srivastava 2012). At the same, a study from rural Pakistan shows that "left-behind" girls in migrating families have better access to education than boys, leading to significant decrease in gender inequalities (Mansuri 2006). Among pastoralists, children staying with the herds are unable to sustain school attendance, which leads to systematic exclusion of boys; but when the household splits to enable school enrollment, social norms may prioritize enrolling boys in school and deploying girls to household management.

So far, "organized and rigorous" research about the actual impact of a human rights framework on policies of education across South Asia is hardly present (Bajaj and Kidwai 2016). Although the 1989 UN Convention on the Rights of the Child is ratified by all countries in South Asia, legislation that can enable the right to education is often weak and/or poorly enforced. Laws that protect migrant workers' basic rights to housing and other entitlements do exist, but legal frameworks that should ensure labor and social security rights are often inadequate, replete with loopholes and unenforceable regulations (Srivastava and Pandey 2017). Internal migration policies (on seasonal migration, in particular) or migrant-specific labor policies are few in number, compared to those that address international migration (Srivastava and Pandey 2017). India, which has separate legislation on internal migration (the Inter-State Migrant Workmen Act 1979), is the only country in South Asia that, at least in theory, legally provides for regulatory measures towards working conditions of such migrants (Srivastava and Pandey 2017). Nevertheless, even there, non-governmental organizations (NGOs) working with children from seasonally migrating families, as reported in Bengtsson and Dyer (2017), have called for tougher punitive measures for breaches of legislative frameworks and better enforcement of existing legislation and agreements that support education and human rights, especially for girls.

Such measures have very little relevance for mobile pastoralists. For them, rights struggles tend to focus on access to natural resources and demonstrate unresolved tensions between "traditional" user rights for the commons and private/public land ownership. In such struggles, pastoralists' widespread exclusion from formal education hampers their ability to speak back to those in positions of power (Dyer 2014). 


\section{Education, Human Capital Development, and Poverty Alleviation}

While an explicit focus on education as a human right has been gaining momentum since the EFA movement began in the 1990s, policy narratives in the region have long affirmed formal education as an individual and social good, a key driver of economic growth and development, and as a means of developing human capital and reducing inequalities associated with social hierarchies, particularly caste and gender (GoA 2016; GoB 2010; GoI 2019a; GoP 2017). All South Asian countries, irrespective of the differences of their particular country context, pursue goals of national integration and unity through education. Figure 1 provides an example of this from two national education policies:

In practice, because these policy goals are largely pursued through formal schooling, "inclusion" is a site of tension between policy goals of improving learners' socio-economic position through formal schooling, and the fact that this is a process of drawing learners into the structured system of social inequality that schooling represents (Drèze and Sen 1995). Formal systems of mass public education were themselves conceived within a sedentary paradigm of human life, and (as section "An Ontological Crisis? Modern Schooling and Its Terms of Inclusion” will illustrate) they tend to reproduce this paradigm by default, which discriminates against mobility-dependent livelihoods. Further, formal education is seen in state policies as instrumental in the growth of "human capital" on which the modern economy depends, by enabling individuals to develop the skills and knowledge they need to participate in this economy. From this perspective, skills and knowledge that do not serve the intent or needs of modernity are liable to be constructed as

\section{Education Policy, Pakistan 2017 - 2025}

Education is the only source of human capital formation and producing responsible citizens in the country. Therefore, education has always been the major concern of successive governments in Pakistan since its inception. The progress of a country or a nation depen ds on the quality education. Education is therefore considered as a pre-requisite for combating poverty, raising productivity, improving living conditions, protecting the environment and making enlightened citizen. Further, poverty alleviation and integrated human development, universalizing access and quality education, women empowerment and elimination of all forms of discrimination, community mobilisation and strengthening partnership of Public and Private Sector are the priority goals and commitments of the present government.

Source: $\operatorname{GoP}(2017$, p. 4).
National Education Policy, Bangladesh 2010

The primary objectives of this policy are directed toward the cultivation of human values. It seeks to prescribe ways through which citizens can be groomed to become leaders in pro-people development programs and progress of the society. They will become rational and intellectually accomplished human beings with ethical perceptions, who have respect for their own religion as well as for others' faiths. Education will help them to grow up as noncommunal, patriotic and efficient persons free from superstitions. And simultaneously, it is only education that can equip the nation to acquire the qualities and skills that will strengthen Bangladesh to work with equal capacity and pace of the global community.

Fig. 1 Promoting national integration and unity: two national education policies 
irrelevant. Mobility-dependent livelihoods are, as we have seen, located in contradictory ways within the modern nation state, a positioning that reflects contestations over the nature and value of the "human capital" associated with people pursuing these livelihoods. Schooling, then, can be part of a state project of educating people into modernity, to improve their capital, and out of livelihoods that modernity delegitimizes. Unsurprisingly, then, whether formal education develops human capital that is of value to those who pursue these occupations is also contested, and schooling may then be resisted.

These arguments can be well illustrated with reference to mobile pastoralists. Any notion of them as citizens of (equal) value to the nation state is undermined by historical state effort to sedentarize and regulate them (Agrawal and Saberwal 2004). Among mobile pastoralists, animal holdings have traditionally constituted both social standing and economic wealth. Productivity is not the only important orientation of their livelihood, spirituality and human-animal relationships are too. Indicators of material wealth that are associated with sedentary populations, or calculating a poverty line, have limited relevance for people who move and count much of their wealth in terms of animals. Traditionally, labor for pastoralism is provided from within the (extended) family, including children, according to gendered norms governing who undertakes which tasks. For children, this situated livelihood learning integrates them as productive members of the herding unit (Dyer 2014) and is a process of human capital development intrinsic to pastoralism, although it may be perceived incorrectly by outsiders as "wasting time" (Murtaza et al. 2016). While pastoralists see that basic formal literacy and numeracy skills can facilitate their livelihood by providing access to information (Dyer 2014), the knowledge that is useful for pastoralism and the curricular content of schooling otherwise fail to connect.

The inaccessibility of formal schooling has historically not necessarily inconvenienced mobile pastoralists, give its limited relevance to their livelihood (Rao 2006). This is, however, changing. Across South Asia, unsympathetic policies, insecurity, and climate change - along with changing youth aspirations - intersect to create conditions that undermine the sustainability of mobile pastoralism. Many families are experiencing pressures to reduce their stock, generate a cash income, sedentarize, and seek alternative occupations. In such circumstances, formal schooling takes on a new relevance, as it enables livelihood diversification and an exit route from pastoralism. Trends of increasing school enrollment in pastoralist areas that are associated with this instrumental use of schooling can be read it two ways. A positive one is that school enrollment reflects intentional use of the formal education system within a managed process of diversification. A less positive one is that it reflects the difficulties many pastoralists are now facing in recovering from shocks, such as animal death from drought or illness. Behind the child in school may be a family whose stock of animal assets is too low to viable, and whose social networks are strong but not necessarily able to facilitate re-stocking or employment in the nonpastoralist sphere, and whose parents lack the formal education that can support gaining good quality paid work. 
In contrast to pastoralist migration, which - often simply by its omission - is perceived in dominant policy discourses as not relevant to modern economy, seasonal and short-term migrants are part of the workforce that is integral to many modern labor sectors. In India, one study has suggested that circular migrants contribute $10 \%$ to national GDP (Deshingkar and Akter 2009). They are a source of "cheap" labor in the modern capitalist economy; and increased informalization and casualization of labor across the region have made migrant labor central to economic growth and development. Yet at the same time, internal migration often entails restricted citizenship status, whether in terms of legality, rights, identity, or belonging (Abbas 2016). Temporary/seasonal labor migration is largely undertaken by poorer and socially marginalized families. This form of migration is a means of subsistence and survival strategy for the poorest and socially marginalized people in rural areas; and for those with least skills and education (de Haan and Yaqub 2010; Keshri and Bhagat 2012; Srivastava 2012). Such migrants are often employed in informal and vulnerable labor sectors, in which working conditions are difficult, and labor rights and social welfare policies are least implemented (Deshingkar et al. 2012; Morpeth et al. 2009). Education can be an effective means of poverty reduction and livelihood diversification, but precarity and informality of labor shape circumstances of mobility, which in turn affects children's access to education (Rao 2010). A study in Dhaka city shows that rural-urban migrant families living in poor urban areas spend comparatively less on education than non-migrant families and that children from the former category achieve lower levels of education (Cameron 2012).

For many seasonally migrating families, it is highly likely that parents will take children with them to cities: they often lack extended family support for child care at home, residential facilities to support children's schooling in villages are often of low quality, and children's work contributes to the family's survival in the city. Rajan (2018) reports that in southern India, children who migrated with their families to the city undertake sibling care, watch over the tents while adults are away for work, and do domestic activities such as cooking, cleaning, and fetching water. They, too, invest selectively in schooling based on their circumstances of mobility and livelihood requirements.

Poverty and uncertain contexts of mobility are shown to affect educational opportunities of internally migrant children adversely (GEMR 2018). A quantitative study in 70 villages in rural north-western India with 1980 children belonging to short-term migrant families shows that there is significant statistical difference between the educational attainment of migrating and non-migrating children (Coffey 2013). Studies in India show that while migrant remittances positively influence the education access and gender gap of "left-behind" children, "accompanying" migrant children are likely to drop out of school or engage in child labor (Roy et al. 2015; Schapiro 2009). Similarly, Mansuri (2006) shows that in rural Pakistan, left-behind children in migrant households are more likely to attend school and less likely to be engaged in child labor.

The recent outbreak of the COVID-19 pandemic has thrown into sudden and sharp relief the precarity of millions of seasonal workers, who were compelled 
suddenly to return home with no assurances of support or alleviation of hunger; and of pastoralists, whose livelihood depends on being able to move freely. Critical events, of which this is an extreme example, often interact with the informal and vulnerable contexts of mobility-dependent lives, highlighting the fragility of "citizenship" and leading to unexpected and adverse effects on children's education (Rajan 2019).

\section{Approaches to Education Inclusion for Internally Migrating Children}

This section reviews how education inclusion for internally migrating children has been approached. It begins with discussion of why expanding school-based, elementary education, which has been the dominant response to improving education access in South Asia, has largely excluded internally migrating children. It then examines "alternative" provision, and evidence of experimentation that has seen some success, but also raises equity issues.

\section{An Ontological Crisis? Modern Schooling and Its Terms of Inclusion}

South Asia's current development regimes situate migration-dependent livelihoods in complex and contested positions. These regimes are largely unable to respond to the education needs of children in families who pursue these livelihoods.

The geospatial zones that are home to mobile pastoralists and many seasonal labor migrants are often known to others as "interior" or "remote rural" locations. In India, Pakistan, and Afghanistan, these include areas that are insecure and/or are conflict-prone border areas. Such locations typically have a low population density, and common infrastructural deficits in education systems including teacher shortages, poor material conditions, and absence of water and sanitation facilities. In Afghanistan, discourses of education inclusion for mobile pastoralists have been infused with a focus on education as a security priority rather than as a basic right (Dyer 2016). Information deficits and absent relations between state agencies and communities leave wide gaps in accountability for children's education and achievement of learning outcomes (Smita 2008; Bengtsson and Dyer 2017). At the same time, authorities' tendency towards a supply rather than demand-orientated stance to service provision is implicated in a lack of co-planning and limited community ownership of state-provided education (Dyer 2014).

If barriers to initial access can be overcome, fluctuations in enrollment of children from mobile populations are common and predictable, reflecting both time of year and location (Smita 2008). Schools have standard features that are rarely questioned, such as daily timing, annual calendar, requirement of daily presence, and age for grade structure of progression. These features of schooling impose what Dyer (2013) calls "terms of inclusion" that migrating families have to negotiate. For example, the formal school calendar is poorly adapted in several ways to the seasonality and 
nature of movement, which tends to result in a pattern of initial enrollment but subsequent drop out from school once the child migrates away from the place of permanent residence. The organization of the school day is often also a barrier for children who need to attend to livelihood-related duties at times of the day when they are supposed to be in school.

Although inclusion in schooling is widely assumed in policy discourses to promote social inclusion, this relationship can also be a process of "adverse incorporation" (Dyer 2012). Among pastoralists, schooling conflicts with livelihood management strategies that combine mobility with labor organization and "learning on the job" (Dyer 2014), which usually enforces choosing one or the other form of learning. Learning content in school that does not feature pastoralist culture, or values, or celebrate its knowledge, for example, provides a hidden curriculum that devalues this livelihood. Tensions between the social values of pastoralists and other school-using communities are reported from India (Dyer 2014), while a study with migrant children in Dhaka city (Giani 2006) shows that poor quality of schooling and difficult relationships with teachers may shape children's decisions to migrate to the city.

A strong policy focus on universalizing access has not paid adequate attention to ensuring participation and retention. Guaranteeing "attendance" and "completion" of elementary education for migrating children is a massive task (Chandrasekhar and Bhattacharya 2018); and in schools, informal practices of exclusion and discrimination persist (Coffey 2013; Dyer 2014). Arrangements to help learners catch up with missed work are usually lacking. Teachers are often reluctant to re-enroll children who have temporarily left and may not consider taking extra measures for migrating children as their responsibility (Coffey 2013). Absence prevents children from developing the relationships with teachers and classmates that help them progress (Coffey 2013). If a child is successfully re-enrolled, missed learning may lead to low performance and demotivation, and often it is the student who is blamed, explicitly or implicitly, for falling behind (Smita 2008). Insufficient prior learning and gaps of attendance often mean that, regardless of age or learning needs, inflexible school procedures force students to repeat the same grade. No detention policies have been widely adopted to address this, and to ensure progression through schooling until the end of the elementary cycle (e.g., Section 16 of India's RtE Act). The reversal of this policy in India in 2019 is said to affect negatively children from marginalized communities (Rai and Majumder 2019) and, given the context of mobility, migrant children are likely to be among the worst affected by this policy change.

Despite policy and public discourses around the "modernizing" process of formal education and the influence of this image on familial aspirations and expectations, its effect on migrating children and young people is dependent on their socioeconomic context, individual circumstances, and household level characteristics (Heissler 2017; Rao 2010). Research on children in seasonally migrating families demonstrates clearly that perceptions on the value of formal schooling and its relationship to both economic productivity and social status vary significantly according to context (Rao 2009). Where the informal labor market structure provides children with good opportunities for employment and sale of produce, working can be more 
attractive than schooling: processes of modernization are opening channels - such as consumption - that may more effectively and quickly deliver elevated social status and incomes than schooling, if local labor markets are conducive (Rao 2009). Also, work, whether paid or unpaid, and intergenerational dependence are integral to the lives of children living in economically and socially marginalized contexts (Heissler 2017) and can be a valued source of respect and aspect of belonging.

For families undertaking livelihood-related mobility, investing in school attendance involves negotiation and careful decision-making at the household level. For those children who do access schooling, their experience is shaped by struggles to remain within the schooling system, and to "catch up," which make the questions of whether the education they receive leads to substantial learning or upward social mobility highly pertinent. For many other internally migrating children, formal schools are completely out of reach.

Rajan (Rajan forthcoming) identifies this as the "ontological crisis of modern schooling," building on Dyer's (2014) argument that "geo-spatially fixed schooling," and the terms of inclusion (Dyer 2013) on which it comes, creates exclusion for mobile children. Modern schooling systems embody this fundamental crisis through their mutually constituted and "immobile" ideals (such as age, grade, learning level, curriculum, and language of learning) which position migrating children in a constant state of facing and attempting to mitigate a "learning crisis." The very design of modern schooling, which offers the promise of inclusion for all on terms that are exclusionary for migrating children (Dyer 2013), and its inability to adapt, constitutes its ontological crisis. Recognition of this ontology challenges the dominant perception that failures of inclusion are an inevitable outcome of mobility and that they lie in the failures of migrating populations themselves to access the schooling system.

We turn, in the next section, to considering alternative efforts made in the region to "include" mobile children, while recognizing that these efforts have not been able to question the ontological crisis of modern schooling at a fundamental level.

\section{Leaving No-One Behind by Increasing Education System Flexibility}

The 1990 EFA declaration underlined the need for flexible provision that is responsive to differing learning needs, and this need was reiterated in Dakar in 2000. The rights-based nature of both these calls encouraged the development of forms of education provision that respond to the right to education in a fuller sense, and can deliver meaningful learning within, and for, mobile livelihoods. In South Asia, efforts have included making provision mobile; offering residential schools and hostels; extending "alternative" basic education at scale via the state system or via smaller, non-state provision; and use of open learning. Morpeth et al. (2009) provide a summary (Table 2) that shows the diversity of provision, although the wide range of possibilities it covers may not address the specific needs of internally migrating children. 
Table 2 Types of para-formal and alternative schooling systems and the exclusion addressed

\begin{tabular}{|c|c|c|c|c|}
\hline Type & Examples & Providers & Coverage & $\begin{array}{l}\text { Exclusions } \\
\text { addressed }\end{array}$ \\
\hline \multirow[t]{4}{*}{$\begin{array}{l}\text { Open } \\
\text { schools }\end{array}$} & $\begin{array}{l}\text { National Institute } \\
\text { of Open Schooling } \\
\text { (NIOS) India }\end{array}$ & Parastatal & National & \multirow{4}{*}{$\begin{array}{l}\text { Wide range of hard } \\
\text { to reach groups } \\
\text { requiring } \\
\text { alternative service } \\
\text { delivery models - } \\
\text { children, youth, and } \\
\text { adults }\end{array}$} \\
\hline & $\begin{array}{l}\text { Bangladesh Open } \\
\text { School (BOS) }\end{array}$ & Open University & National & \\
\hline & $\begin{array}{l}\text { Sri Lanka Open } \\
\text { School (SLOS) }\end{array}$ & $\begin{array}{l}\text { National Institute of } \\
\text { Education }\end{array}$ & National & \\
\hline & $\begin{array}{l}\text { Pakistan Open } \\
\text { School (POS) }\end{array}$ & Open University & National & \\
\hline \multirow[t]{2}{*}{$\begin{array}{l}\text { Community- } \\
\text { based } \\
\text { schools }\end{array}$} & $\begin{array}{l}\text { Community } \\
\text { Organized Primary } \\
\text { Education (COPE) } \\
\text { initiative, CARE } \\
\text { Afghanistan }\end{array}$ & $\begin{array}{l}\text { NGO initiated but } \\
\text { typically } \\
\text { partnerships of } \\
\text { INGOs (e.g., SC, } \\
\text { UNICEF), MoE } \\
\text { and local NGOs }\end{array}$ & $\begin{array}{l}\text { Mainly } \\
\text { rural } \\
\text { areas }\end{array}$ & $\begin{array}{l}\text { Lack of access to } \\
\text { schools, often in } \\
\text { rural areas }\end{array}$ \\
\hline & $\begin{array}{l}\text { BRAC, } \\
\text { Bangladesh }\end{array}$ & Large NGO & $\begin{array}{l}\text { National, } \\
\text { rural and } \\
\text { urban }\end{array}$ & $\begin{array}{l}\text { Lack of access in } \\
\text { rural areas, but also } \\
\text { cater to specific } \\
\text { groups, e.g., street } \\
\text { children, migrant } \\
\text { workers, language } \\
\text { minority groups, } \\
\text { IDPs, refugees }\end{array}$ \\
\hline $\begin{array}{l}\text { Low-cost } \\
\text { private } \\
\text { schools }\end{array}$ & $\begin{array}{l}\text { Low budget private } \\
\text { schools in many } \\
\text { South Asian } \\
\text { countries }\end{array}$ & Private enterprise & $\begin{array}{l}\text { Urban } \\
\text { and peri- } \\
\text { urban } \\
\text { areas }\end{array}$ & $\begin{array}{l}\text { Low-income } \\
\text { groups in urban and } \\
\text { peri-urban areas, do } \\
\text { not address } \\
\text { exclusion of } \\
\text { poorest or non- } \\
\text { income poorest, e. } \\
\text { g., gender, caste }\end{array}$ \\
\hline $\begin{array}{l}\text { Faith-based } \\
\text { schools }\end{array}$ & $\begin{array}{l}\text { Madrasas (Islamic } \\
\text { religious } \\
\text { seminaries) in } \\
\text { Pakistan, } \\
\text { Afghanistan, India }\end{array}$ & $\begin{array}{l}\text { Faith-based } \\
\text { organizations }\end{array}$ & $\begin{array}{l}\text { Urban or } \\
\text { rural } \\
\text { areas }\end{array}$ & $\begin{array}{l}\text { Responsive to } \\
\text { differentiated } \\
\text { demand and may } \\
\text { include moral } \\
\text { obligation to cater } \\
\text { for the poor }\end{array}$ \\
\hline \multirow[t]{2}{*}{$\begin{array}{l}\text { Schools run } \\
\text { by charitable } \\
\text { organizations }\end{array}$} & $\begin{array}{l}\text { Pushpa Vidyalaya } \\
\text { - St Agnes' Loreto } \\
\text { Day School, } \\
\text { Lucknow, India } \\
\text { (elite private } \\
\text { school with } \\
\text { outreach programs) }\end{array}$ & \multirow[t]{2}{*}{$\begin{array}{l}\text { Philanthropic } \\
\text { associations funded } \\
\text { by corporations, } \\
\text { individual } \\
\text { donations and trusts }\end{array}$} & \multirow[t]{2}{*}{$\begin{array}{l}\text { Urban or } \\
\text { rural } \\
\text { areas }\end{array}$} & \multirow[t]{2}{*}{$\begin{array}{l}\text { Responsive to } \\
\text { differentiated } \\
\text { demand and may } \\
\text { include moral } \\
\text { obligation to cater } \\
\text { for the poor }\end{array}$} \\
\hline & $\begin{array}{l}\text { Aga Khan } \\
\text { Foundation schools } \\
\text { in northern areas, } \\
\text { Pakistan }\end{array}$ & & & \\
\hline
\end{tabular}

Source: Adapted from Morpeth et al. (2009) 
With respect to seasonally migrating children, specifically, the state and NGOs in India have been working on a number of interventions in various geographical areas (Smita 2008). These include seasonal hostels in origin areas (e.g., by Sankalp in Gujarat, Janarth in Maharashtra); schools in destination areas in the form of work site schools (e.g., sakharshalas in sugarcane cutting sites, bhongashalas in brick kilns, and pashanshalas in stone quarries in Maharashtra); mobile interventions (e.g., transporting mobile Oriya teachers from Orissa to Andhra Pradesh by ActionAid); and bridge courses (e.g., AIF, Vikalpa, and Lok Drishti in Orissa and Andhra Pradesh) and activity centers in destination sites (e.g., SETU Gujarat). Many of these projects run interventions both in origin and destinations areas (Bengtsson and Dyer 2017).

Prominent forms of flexible educational provisioning and some of the challenges associated with them are explored below, beginning with examples of innovations intending to improve retention within the formal schooling system, and then discussing "alternative" provision.

\section{Networked Schooling}

Networked schooling is an innovation within the formal schooling system and as such reflects both the advantages and disadvantages associated with mainstream provision. For many migrating children, the convention of enrolling in one school for the whole year needs to be adjusted to reflect the realities of their lives. These children could benefit from being able to enroll in not just one, but rather, in several schools across the network of provision (Dyer and Echessa 2019). This offers freedom to continue a learning program that is not bound to one place, which is a "term of inclusion" imposed by conventional schooling. An attempt to do this in government schools in Gujarat in India, focusing on seasonal migrants, used a migration register to know migration trends (direction, destination, duration, timings, who goes, etc.) but was discontinued because state actors felt the level of support required exceeded state capacity (Dyer 2014). An innovation of this nature is likely to be overwhelmed by the highly variable movement of mobile pastoralists but has potential where fewer transitions are needed, such as among migrating laborers adopting a seasonal, circular migration pattern from the place of outmigration to a destination site. However, in many government schools, there is already concern over weak basic infrastructure and poor learning conditions, without addition of other learners who will have only a temporary presence (Bengtsson and Dyer 2017); funding norms are not designed to accommodate variability of this nature; and improving access to a school does not necessarily lead to successful inclusion.

\section{Residential Schools}

Residential schools offer continuity in fixed place provision by including boarding facilities, but while they can enable access, they are often also places of discrimination, limited support, and physical and sexual exploitation. The positive intention of assisting children identified by the state as needing special protection can perpetuate rather than address social segregation, as Rao (2006) found in relation to pastoralists in Jammu and Kashmir, although conversely, Dyer (2014) reports that segregation 
and supporting community values are essential to the success of a pastoralist residential school in Gujarat. Similarly, India's Kasturba Gandhi Balika Vidyalaya scheme (KGBV) scheme, in which a reported number of 5,970 residential schooling facilities are said to reach 7.25 lakh girls from poor socio-economic background (GoI 2019b), is critiqued for being operated through the patriarchal assumptions of protection, surveillance, and alienation (Saxena 2012). Sending children to a residential school while their parents migrate may be detrimental to the child's wellbeing and development, although this aspect has not been much studied (Rajan 2018). Residential schools also require children to forgo the opportunity for "situated learning" within their communities.

\section{Seasonal Hostels}

Establishing a seasonal hostel, or residential care centre, at the point of departure helps children remain in the place of permanent residence and at school. In eastern India, an NGO has developed a model that supported nearly 20,000 children between 2013 and 2016: a hostel that works on a cluster basis, serving several villages, which is funded by draw-down funding from the national Sarva Shiksha Abhiyan (SSA) program, with external partner support, and involves School Management Committees. This NGO, and another operating a similar program in western India, both report that seasonal hostels can be instrumental in improving social integration for migrating low caste/Adivasi communities if providers also involve non-migrating village children, so all children interact and participate in activities held in the hostel (Bengtsson and Dyer 2017).

It is generally claimed that it is better to leave the children behind in villages when families migrate because of the "hazardous" work environments and lack of access to resources and education in destination sites; and that seasonal hostels are better long-term solutions (Smita 2008). This claim does not take into account the emotional challenges of separation or the intergenerational dependence on children's work in seasonally migrating families that enables them to survive in the city (Rajan 2018).

\section{Bridge Schools}

Bridge schools attempt to reintegrate children who have missed school into mainstream provision. They provide short-term, catch-up provision, and usually focus on re-enrollment in the "home" school in places of high outmigration. However, children who accompany parents should be eligible to attend school in the place of in-migration, which may necessitate support with both initial enrollment and retention. This need is not so well recognized (Babu et al. 2017). The "Urban Slum School" and "Bridge School" projects run jointly by the NGOs BRAC and EAC for children from vulnerable and disadvantaged backgrounds who are living in slums areas in various cities of Bangladesh are examples of interventions run in destination areas (EAC n.d.-b, n.d.-c). Ensuring any continuity via this form of support can be difficult: in Mumbai, one NGO acknowledged it had no capacity to follow-up children it had supported in "receiving" area schools once they set off back home (Bengtsson and Dyer 2017). 
Bridge schools have obvious merits, but they tend to be stop-gap arrangements in which practices are disparate, quality is uneven, and continuity is not monitored. Rajan's (2018) empirical work in Karnataka showed that lack of systematic planning and absence of enduring commitment towards children's learning make many NGO bridging schools places where children avail of nutrition and recreation facilities, but no substantial learning takes place. In contrast, high quality bridge schooling in Gujarat and Odisha is reported to have enabled thousands of children to reintegrate successfully into their "home" school after absence (Bengtsson and Dyer 2017).

\section{Mobile Schools}

It is widely assumed in policy and some scholarly discourses that in order to serve mobile populations, schooling itself must be mobile. This leads to recommendations that provision in a tent, boat, or bus is the obvious solution to exclusion of communities who cannot access schooling (e.g., Suliman et al. 2017). "Mobile" schools can offer the formal "school" curriculum, or an alternative. In either case, they enable access by moving with the migrating group, or by bringing resources to where the learners are. In Bangladesh, for example, boat schools were innovated to serve the peripatetic Bede community; and in the Haor basin flood plain, EAC and BRAC now run a collaborative "Boat School" project that targets 13,000 "hard to reach" OOSC in disaster prone and remote rural areas (EAC n.d.-a), where difficult geographical and weather conditions, lack of schools, and inadequate transportation and communication facilities make educational provisioning challenging. A practical limitation of mobile schooling among mobile pastoralists is that the constellation of learners is not necessarily constant as groups may split if resource availability requires it (Dyer 2014). Sharifi (2013, p. 12) reports from Afghanistan, for example, that "If we have mobile schools, we [...] may need 5 teachers when we are in one location, but when we move to another location, the need may raise to 10 , because we are normally fragmented [...] when moving from one location to another."

A hybrid "mobile" school, provided by the government in India's Jammu and Kashmir for Bakkarwal pastoralists, comprised a home and a seasonal school covering the months of the year children are in high pastures. Suri (2014) reports "pathetic" condition of the seasonal school component, with lack of infrastructure, despite government claims that tents and other materials had been provided, "haphazard" learning in disorganized multigrade, multi-subject teaching and a demotivated, underpaid teacher in provision that the state failed to monitor.

\section{Alternative Basic Education Provision}

Non-formal provision, widely termed Alternative Basic Education (ABE) in the EFA movement, is broadly understood as non-formal education programming for those unable to use the formal schooling system. Such provision is usually seen to have advantages of small classroom size, flexible curriculum and timings, child-centered pedagogy, and teachers from the local community (GMR 2014). In South Asia, examples relevant to internally migrating children include Community-Based Education (CBE) in Afghanistan, Alternative and Innovative Education (AIE) in India, and Alternative Learning Programme (ALP) in Pakistan. India, however, has 
discontinued its AIE provision, as the RtE's notion of quality and neighborhood schooling precluded the flexible parameters for responsive provision that characterized AIE, legally requiring it to be phased out.

The appeal for migrating groups is that $\mathrm{ABE}$ can be unconstrained by form. It can be provided in temporary accommodation; it may be "mobile" or in one place; it can offer flexibility over curricular content and pace; it respects community social values; and has capacity to investigate and respond to demand. It often has particular strengths in providing conditions that are conducive to enrolling and retaining girls. Afghanistan's CBE for newly settled pastoralist communities, run by the Swedish Committee for Afghanistan in close collaboration with government, has shown all of these strengths and an impressive willingness to develop recognized, equivalent qualifications (Dyer 2016; Sharifi 2013).

$\mathrm{ABE}$ is also widely conceived as a "second chance" for marginalized communities (Banerji 2015), often via accelerated learning programs. Pakistan, for example, has about 16,000 non-formal basic education (NFBE) institutions, largely comprising community-based schools: accelerated learning is the dominant strategy within NFBE provisioning (UNCF 2017). Huge variations are reported among provinces, however, with about $90 \%$ of provision located in Punjab and just $0.2 \%$ in Sindh.

All governments place extensive reliance on civil society organizations for funding and delivery of $\mathrm{ABE}$ provision, which draws into question how the state understands its responsibility for marginalized learners.

\section{Open Learning}

An open schooling system is expected to cater to a diverse range of learners, through distance education, and removes barriers of time and space that are associated with place-based provision (Morpeth et al. 2009). It enables flexibility and a learnercentered approach, and also offers formal accreditation through programs that are equivalent to formal education (UNCF 2011). Through modern technologies and multiple learning modes, an open learning system is capable of providing quality that compares favorably with a formal education system (examples in South Asia were shown in Table 2). NIOS, for example, runs various programs such as Open Basic Education (OBE) Program (for 14+ years age group, adolescents and adults at levels equivalent to grades III, V, and VIII of the formal school system); secondary education course; senior secondary education course; vocational education courses and other "life enrichment" programs. SLOS, similarly, provides education in war, disaster, and drought hit areas, and to internally displaced persons and refugees (Morpeth et al. 2009).

While features of open provision such as geographic flexibility, choices in language of instruction, flexible admission and program completion, and individualized pacing (Abrioux 2009) may seem amenable to the lived realities of migrant children, they are not of themselves enough. Systemic support and structural changes are needed to make sure that such provision does not remain as inaccessible as formal schooling to children from migrating communities. Regional dialogue initiated by the Commonwealth Secretariat in collaboration with NIOS in 2006 on open and flexible learning for migrant populations (Morpeth et al. 2009) did not lead 
to sustained follow-up. In general, across South Asia, most of the potential benefits of an open learning system for migrating children have yet to be fully investigated or proactively and systemically supported.

\section{Conclusion}

There are many gaps in the academic literature around the nature and extent of relationship between migration and education in South Asia. Although there is a "gray" literature which provides some useful information, this literature is diffuse, often anecdotal and often written in a "reporting" format that focuses on numbers, targets, and outcomes. Systematic, scholarly studies that provide detailed empirical findings about the lived realities of internally migrating children and their experiences of education do exist, but are in very short supply. Questions about the role of education in social integration, economic mobility, and learning outcomes, which are widely discussed in relation to international and refugee migration (Nicolai et al. 2017), are equally pertinent for children in internally migrating families - yet they are rarely being asked, let alone answered.

While policy narratives posit formal education as having intrinsic and universal value, we have shown that there are no straightforward relationships in the complex nexus of education, migration, development, livelihoods, and poverty. Mobile pastoralism, for example, intrinsically offers productive opportunities of livelihood and situated learning, yet frameworks of the modern economy operate to delegitimize this production system, and to narrow the frame of what counts as "education." For seasonal migrants, mobility offers a means to diversify family livelihood opportunities, but because seasonal/short-term/circular migration is often undertaken by disadvantaged sections of society, the inequalities they face are compounded by aspects of caste, class, gender, region, and religion; and for many also, the exploitation of illegal, "hazardous" work.

The overall argument of this chapter is that modern education systems are inadequate in design to incorporate the lived realities and educational needs of children in mobile pastoralist and seasonally migrating families. We have called this the "ontological crisis" of modern education (Rajan forthcoming). The normative and operational parameters of "mainstream" schooling impose "terms of inclusion" (Dyer 2013) that discriminate against children in such families. Attempts to make the formal system somewhat more flexible may perhaps improve the prospects of continuity for migrating children, which the literature emphasizes as important (Babu et al. 2017), but do not fundamentally address the persistently discriminatory design of modern schooling.

The "alternative" provision that is advocated in global and regional policy may address some of the unfavorable "terms of inclusion" of formal schooling, but differential provisioning for marginalized communities to enable "inclusion" has many downsides. While the stimulus to "alternative" thinking is welcome, ABE has many limitations as a concept and as a practice. The growing acceptance of ABE at policy level as a legitimized "solution" for children from marginalized communities 
is challenged by scholarship that shows it to be often sporadic, piecemeal, and to trade flexibility for quality of learning, and raises questions over quality, equity, sustainability, and social integration. Rampal (2000), for example, critiques the politics embedded in the flexible curriculum of "those" children and the "highly guarded curriculum" of "our children." She argues that non-formal education programs in South Asia have largely not only been unable to implement good quality interventions but also have not been able to change the formal schooling system in fundamental ways. Inequalities are perpetuated by legitimizing a parallel system, although with its focus on only lower levels of "basic" education, this "system" is an incomplete alternative to "mainstream" schooling: children who complete their ABE learning program have to resort to mainstream provision if they wish to progress further. Furthermore, since official recognition of $\mathrm{ABE}$ remains variable and often limited, children enrolled in such provision may be officially recorded as out of school, which makes it difficult to assess its scale and impact (Rose 2009).

In sum, formal and "alternative" programs can be equally exclusionary, albeit in differing ways, for children from internally migrating communities unless issues of access, quality, and equity are meaningfully addressed. The principles of "no one left behind" and "reaching the furthest behind first" are the core moral exigencies of the 2030 Agenda for Sustainable Development. With respect to education, this means ensuring "inclusive and equitable quality education" and promoting "lifelong learning opportunities for all." While "left-behind" children are now an articulated, central focus of global policy discourses around educational inclusion, the sociopolitical and moral contingencies that shape the production of a "left-behind child" need to be much more closely scrutinized. There is an urgent need for more, nuanced, cross-disciplinary scholarship that examines how dominant educational and developmental frameworks operate within an exclusionary ethos, and thereby critically engages with the understandings of inclusion that are postulated in policy and manifested in practice.

\section{Cross-References}

Child Labor and Education in South Asia

Poverty and Education in South Asia

\section{References}

Abbas, R. (2016). Internal migration and citizenship in India. Journal of Ethnic and Migration Studies, 42(1), 150-168. https://doi.org/10.1080/1369183X.2015.1100067.

Abrioux, D. A. M. X. (2009). Special issues and practices in open schooling. In D. Abrioux \& F. Ferreira (Eds.), Perspectives on distance education: Open schooling in the 21st century (pp. 318). Vancouver: Commonwealth of Learning (COL).

Agrawal, A., \& Saberwal, V. K. (2004). Whither South Asian Pastoralism? An introduction. Nomadic Peoples, 8(2), 36-53. JSTOR. 
Babu, S., Kumar, A., Baskar, V., \& Dash, U. (2017). What are the effects of various interventions and approaches used for enhancing poverty reduction and development benefits of "within country migration' in South Asia? A systematic review and contextualisation report on implication of evidence for South Asia. DFID. https://www.gov.uk/dfid-research-outputs/what-arethe-effects-of-various-interventions-and-approaches-used-for-enhancing-poverty-reductionand-development-benefits-of-within-country-migration-in-south-asia

Bajaj, M., \& Kidwai, H. (2016). Human rights and education policy in South Asia. In K. Mundy, A. Green, B. Lingard, \& A. Verger (Eds.), The handbook of global education policy (pp. 206-223). Chichester: Wiley. https://doi.org/10.1002/9781118468005.ch11.

Banerji, R. (2015). Second chance programmes in South Asia (Background paper prepared for the education for all global monitoring report 2015). UNESCO. http://img.asercentre.org/docs/ Publications/External\%20publications/gmr_rukmini_2ndchanceprogs.pdf

Bengtsson, S., \& Dyer, C. (2017). Ensuring high quality primary education for children from mobile populations. A desk study. EAC and GIZ. https://educateachild.org/sites/default/files/ docs/2017/EAC_Mobile\%20population_FINAL.pdf

Bernard, A., Bell, M., \& Cooper, J. (2018). Internal migration and education: A cross-national comparison (Background paper prepared for the 2019 global education monitoring report, migration, displacement and education: Building bridges, not walls). UNESCO. https:// unesdoc.unesco.org/ark:/48223/pf0000266070.locale $=$ en

Beteille, T., Tognatta, N., Riboud, M., Nomura, S., \& Ghorpade, Y. (2020). Ready to learn: Before school, in school, and beyond school in South Asia. South Asia Development Forum, World Bank. https://openknowledge.worldbank.org/handle/10986/33308

Bhatty, K., Saraf, R., \& Gupta, V. (2017). Some insights on what we know and what we do not: Out of school children. Economic and Political Weekly, 52(49), 7-8.

Brinkmann, S. (2017). Improving education quality in South Asia: A review of UNICEF's efforts. UNICEF Regional Office for South Asia. http://www.unicefrosa-progressreport.org/attach ments/ED-ROSA-QualityMappingReport-Final2018.pdf

Cameron, S. (2012). Education, urban poverty and migration: Evidence from Bangladesh and Vietnam (Working paper 2012-15). UNICEF Office of Research. https://www.unicef-irc.org/ publications/pdf/iwp_2012_15.pdf

Carr-Hill, R. (2012). Finding and then counting out-of-school children. Compare, 4(2), 187-212. https://doi.org/10.1080/03057925.2012.652806.

Chandrasekhar, S., \& Bhattacharya, L. (2018). Education of children from migrant rural households in India: Moving towards a coherent policy framework (Background paper prepared for the 2019 global education monitoring report). UNESCO. https://unesdoc.unesco.org/ark:/ 48223/pf0000266057

CIER \& UNICEF. (2009). Education in emergencies in South Asia: Reducing the risks facing vulnerable children - Afghanistan. Centre for International Education and Research (CIER), School of Education, University of Birmingham, UK and UNICEF Regional Office for South Asia. https://reliefweb.int/report/afghanistan/education-emergencies-south-asia-reducing-risksfacing-vulnerable-children

Coffey, D. (2013). Children's welfare and short-term migration from rural India. The Journal of Development Studies, 49(8), 1101-1117. https://doi.org/10.1080/00220388.2013.794934.

de Haan, A., \& Yaqub, S. (2010). Migration and poverty: Linkages, knowledge gaps and policy implications. In K. Hujo \& N. Piper (Eds.), South-South migration: Implications for social policy and development (pp. 190-219). Palgrave Macmillan UK. https://doi.org/10.1057/ 9780230283374_6.

Deshingkar, P. (2006). Internal migration, poverty and development in Asia: Including the excluded. IDS Bulletin, 37(3), 88-100. https://doi.org/10.1111/j.1759-5436.2006.tb00272.x.

Deshingkar, P., \& Akter, S. (2009). Migration and human development in India $\mid$ Human development reports (No. 13). United Nations Development Programme. http://hdr.undp.org/en/con tent/migration-and-human-development-india 
Deshingkar, P., \& Grimm, S. (2004). Voluntary internal migration: An update. Overseas Development Institute. https://www.odi.org/sites/odi.org.uk/files/odi-assets/publications-opinion-files/ 70.pdf

Deshingkar, P., Sward, J., \& Estruch-Puertas, E. (2012). Decent work country programmes and human mobility (No. 5; Migrating out of poverty research programme consortium working paper). DFID. http://www.migratingoutofpoverty.org/files/file.php?name=wp5-decent-workcountry-programmes-and-human-mobility.pdf\&site $=354$

Drèze, J., \& Sen, A. (1995). India, economic development and social opportunity. Delhi: Oxford University Press.

Dyer, C. (2012). Formal education and pastoralism in western India: Inclusion, or adverse incorporation? Compare, 42(2), 259-228. https:/www.tandfonline.com/doi/abs/10.1080/03057925. 2011.641359.

Dyer, C. (2013). Does mobility have to mean being hard to reach? Mobile pastoralists and education's 'terms of inclusion'. Compare, 43(5), 601-621. https:/www.tandfonline.com/doi/ abs/10.1080/03057925.2013.821322.

Dyer, C. (2014). Livelihoods and learning: Education for all and the marginalisation of mobile pastoralists. Oxford: Routledge.

Dyer, C. (2016). Evolving approaches to educating children from nomadic communities. Prospects, 46(1), 39-54. https://link.springer.com/article/10.1007/s11125-016-9381-6.

Dyer, C. (2018). Education inclusion as a border regime: Implications for mobile pastoralists in Ethiopia's Afar region. International Studies in Sociology of Education, 27(2-3), 145-165. https://www.tandfonline.com/doi/full/10.1080/09620214.2018.1426998.

Dyer, C., \& Echessa, E. (2019). Sustaining learner participation and progression through networked schooling: A systemic approach for mobile out of school children. International Journal of Educational Development, 64(1), 8-16. Elsevier Ltd. Retrieved 29 Apr 2020 from https://www. learntechlib.org/p/195711/.

EAC. (n.d.-a). Boat schools for rural children. Educate a child: A program of education above all. Retrieved 23 Apr 2020 from https://educateachild.org/our-partners-projects/projects/boatschools-rural-children

EAC. (n.d.-b). BRAC urban slums schools. Educate a child: A program of education above all. Retrieved 23 Apr 2020 from https://educateachild.org/our-partners-projects/projects/bracurban-slums-schools

EAC. (n.d.-c). Bridge school programme for OOSC. Educate a child: A program of education above all. Retrieved 23 Apr 2020 from https://educateachild.org/our-partners-projects/projects/bridgeschool-programme-oosc

GEMR. (2018). Global education monitoring report, 2019: Migration, displacement and education: Building bridges, not walls. UNESCO. https://unesdoc.unesco.org/ark:/48223/pf0000265866

Giani, L. (2006). Migration and education: Child migrants in Bangladesh (Sussex migration working paper no. 33). Sussex Center for Migration Research, University of Sussex. http:// www.childmigration.net/Giani_06

GMR. (2010). Reaching the marginalized: EFA global monitoring report, 2010. UNESCO. https:// unesdoc.unesco.org/ark:/48223/pf0000186606

GMR. (2014). Teaching and learning: Achieving quality for all (Education for all: Global monitoring report). UNESCO. https://unesdoc.unesco.org/ark:/48223/pf0000225660/PDF/ 225660eng.pdf.multi

GMR. (2015). Education for all 2000-2015: Achievements and challenges; EFA global monitoring report, 2015. UNESCO. https://unesdoc.unesco.org/ark:/48223/pf0000232205

GoA. (2016). National education strategic plan (2017-2021). Ministry of Education, Islamic Republic of Afghanistan. http://anafae.af/wp-content/uploads/2016/11/National-Education-Stra tegic-Plan-NESP-III.pdf

GoB. (2010). National education policy 2010. Ministry of Education, Government of the People's Republic of Bangladesh. https://reliefweb.int/sites/reliefweb.int/files/resources/02.National-Edu cation-Policy-2010-English.pdf 
GoI. (2010). Migration in India: NSS 64th round (July 2007-June 2008) (No. 533). National Sample Survey Office Ministry of Statistics \& Programme Implementation, Government of India. http://mospi.nic.in/sites/default/files/publication_reports/533_final.pdf

GoI. (2019a). Draft national education policy 2019. Ministry of Human Resource Development, Government of India. https://mhrd.gov.in/sites/upload_files/mhrd/files/Draft_NEP_2019_EN_ Revised.pdf

GoI. (2019b). Right to education of children of migrant workers. Press Information Bureau, Government of India. https://pib.gov.in/Pressreleaseshare.aspx?PRID=1576065

GoP. (2017). National education policy 2017-2025. Ministry of Federal Education and Professional Training Government of Pakistan. https://planipolis.iiep.unesco.org/sites/planipolis/files/ ressources/pakistan_national_education_policy_2017-2025.pdf

Heissler, K. (2017). Migration and the spaces of labouring and learning for children and young people in Asian contexts. In T. Abebe \& J. Waters (Eds.), Labouring and learning (pp. 201220). Springer. https://doi.org/10.1007/978-981-287-032-2_6.

IOM. (2019). World migration report 2020. International Organization for Migration. https://www. un.org/sites/un2.un.org/files/wmr_2020.pdf

Keshri, K., \& Bhagat, R. B. (2012). Temporary and seasonal migration: Regional pattern, characteristics and associated factors. Economic and Political Weekly, 47(4), 81-88.

Khattak, K. (2018). Right to education (RTE) laws toothless sans rules of business. Right to Education Pakistan. https://rtepakistan.org/news/2018/04/19/right-to-education-rte-laws-tooth less-sans-rules-of-business/

Mansuri, G. (2006). Migration, school attainment and child labor: Evidence from rural Pakistan (No. 3945; World Bank Policy Research Working Paper). Development Research Group, World Bank. https://openknowledge.worldbank.org/handle/10986/8422

Morpeth, R., Creed, C., Cullen, J., Page, E., \& Raynor, J. (2009). Open and distance learning for basic education in South Asia: Its potential for hard-to-reach children and children in conflict and disaster areas. Cambridge, UK: United Nations Children's Fund, Regional Office for South Asia (UNICEF ROSA) \& Cambridge Distance Education Consultancy, Von Hügel Institute, St Edmund's College. http://oro.open.ac.uk/25572/1/ODL_for_Hard_to_Reach_Children_ Main_Report_pdf.

Murtaza, A., Iqbal, J., \& Khaleeq, A. (2016). An evaluation of literacy education present status and future possibilities (with reference to nomad education in AJK). International Journal of Business and Social Science, 7(3), 137-144. https://ijbssnet.com/journals/Vol_7_No_3 March_2016/14.pdf.

Ní Laoire, C., Carpena-Méndez, F., Tyrrell, N., \& White, A. (2010). Introduction: Childhood and migration - Mobilities, homes and belongings. Childhood, 17(2), 155-162. https://doi.org/ $10.1177 / 0907568210365463$.

Nicolai, S., Wales, J., \& Aiazzi, E. (2017). Education, migration and the 2030 agenda for sustainable development. Overseas Development Institute. https://www.odi.org/sites/odi.org.uk/files/ resource-documents/11620.pdf

Rai, A., \& Majumder, S. (2019). Withdrawing the no-detention policy: Punishing children for the system's failure. Social Change, 49(2), 353-360. https://doi.org/10.1177/0049085719844671.

Rajan, V. (2018). Stolen childhoods? Observations on education of migrant children. Economic and Political Weekly, 53(11), 24-27.

Rajan, V. (2019). Gowramma's ghost and Bengaluru's 'zero' out-of-school children. Economic and Political Weekly, 54(40), 30-34.

Rajan, V. (forthcoming). The ontological crisis of schooling: Situating migrant childhoods and educational exclusion. Contemporary Education Dialogue

Rampal, A. (2000). Education for human development in South Asia. Economic and Political Weekly, 35(30), 2623-2631. JSTOR.

Rao, A. (2006). The acquisition of manners, morals and knowledge: Growing into and out of Bakkarwal society. In C. Dyer (Ed.), The education of nomadic peoples: Current issues, future prospects. Oxford/New York: Berghahn Books. 
Rao, N. (2009). Gender differences in migration opportunities, educational choices and wellbeing outcomes, Development Research Centre on Migration, Globalization and Poverty Research Report. www.migrationdrc.org/publications/research_reports.html.

Rao, N. (2010). Migration, education and socio-economic mobility: Editorial introduction. Compare, 40(2), 137-145.

Rao, A., \& Casimir, M. (2003). Nomadism in South Asia. Oxford/New Delhi: Oxford University Press.

Rose, P. (2009). NGO provision of basic education: Alternative or complementary service delivery to support access to the excluded? Compare, 39(2), 219-233. https://doi.org/10.1080/ 03057920902750475.

Roy, A. K., Singh, P., \& Roy, U. N. (2015). Impact of rural-urban labour migration on education of children: A case study of left behind and accompanied migrant children in India. Space and Culture, India, 2(4), 17-34. https://doi.org/10.20896/saci.v2i4.74.

Saxena, S. (2012). Is equality an outdated concern in education? Economic and Political Weekly, 47 (49), 61-68.

Schapiro, K. A. (2009). Migration and educational outcomes of children (No. 57; Human development reports research paper). United Nations Development Programme. http://hdr.undp.org/ en/content/migration-and-educational-outcomes-children.

Sharifi, S. (2013). Education of nomad children in the north and east of Afghanistan: Models, challenges and opportunities (Unpublished Master's submission to Karlstadt University). http:// www.diva-portal.se/smash/get/diva2:709319/FULLTEXT01.pdf.

Sharma. A. (2011). South Asian Nomads - A literature review. CREATE pathways to access research monograph no. 58. https://www.academia.edu/4381223/south_asian_nomads_-_a_lit erature review

Sharma, V.-P., Koeller-Rollefson, I., \& Morton, J. (2003). Pastoralism in India: A scoping study. https://doi.org/10.1080/03057920902750475.

Smita. (2008). Distress seasonal migration and its impact on children's education. Consortium for Research on Educational Access, Transitions and Equity (CREATE). http://www.create-rpc.org/ pdf_documents/PTA28.pdf.

Srivastava, R. (2012). Internal migration in India: An overview of its features, trends and policy challenges. Internal migration in India initiative: National Workshop on Internal Migration and Human Development in India Workshop Compendium. http://www.unesco.org/new/fileadmin/ MULTIMEDIA/FIELD/New_Delhi/pdf/Internal_Migration_Workshop_-_Vol_2_07.pdf

Srivastava, R., \& Dasgupta, R. (2016). Small steps lead the way. American India Foundation (AIF). http://www.shram.org/researchpapers/perspectives/20131210054145

Srivastava, R., \& Pandey, A. K. (2017). Internal and international migration in South Asia: Drivers, interlinkage and policy issues. UNESCO. https://unesdoc.unesco.org/ark:/48223/pf0000249459

Suliman, M., Shah, M., \& Ullah, I. (2017). Addressing the issue of nomadic communities children educational exclusion through mobile tent schools in Malakand, Pakistan. Imperial Journal of Interdisciplinary Research, 3(3), 540-546. https://www.researchgate.net/publication/ 330259387_Addressing_the_Issue_of_Nomadic_Communities_Children_Educational_Exclusion through_Mobile_Tent_Schools_in_Malakand_Pakistan.

Suri, K. (2014). Teaching the nomads in the wild: An analysis of seasonal educational schools for nomadic populations in Jammu and Kashmir. Asian Journal of Multidisciplinary Studies, 2(3), 29-33. http://www.ajms.co.in/sites/ajms2015/index.php/ajms/article/view/215/207.

UN. (1990). International convention on the protection of the rights of all migrant workers and members of their families. United Nations. https:/treaties.un.org/doc/Treaties/1990/12/ 19901218\%2008-12\%20AM/Ch_IV_13p.pdf

UN. (2015). Transforming our world: The 2030 agenda for sustainable development (A/RES/70/1). United Nations. https://sustainabledevelopment.un.org/content/documents/21252030\% 20Agenda $\% 20$ for $\% 20$ Sustainable $\% 20$ Development $\% 20$ web.pdf 
UNCF. (2011). Disparities in education in South Asia: A resource tool kit. Regional Office for South Asia (UNICEF ROSA). http://www.ungei.org/Countering_Disparities_in_Education Toolkit_2011.pdf

UNCF. (2017). Situation analysis of children in Pakistan. UNICEF. https://www.unicef.org/paki stan/media/596/file/Situation\%20Analysis\%20of\%20Children\%20in\%20Pakistan.pdf

UNICEF. (2014). All children in school by 2015: Global initiative on out-of-school children: South Asia regional study covering Bangladesh, India, Pakistan and Sri Lanka. UNICEF Regional Office for South Asia. https://unesdoc.unesco.org/ark:/48223/pf0000226221

UNICEF. (2015). Every child learns: South Asia headline results 2018-2021. UNICEF: For Every Child. http://www.unicefrosa-progressreport.org/childeducation.html

WAMIP. (2015). Pastoralist knowledge hub gathering. South Asia workshop report. Available: https://drive.google.com/file/d/0B6qJcxU8A2KNWVp1TmNVQ3JoTEk/view 